\title{
Companies and Consumers Together for a More Ethical Market ${ }^{*}$
}

\author{
Paolo Pastore $^{* *}$
}

\begin{abstract}
The market of fairtrade products is increasingly present in major large-scale retailers. The fairtrade mark signals that producers and traders have met the fairtrade standards designed to address the imbalance of power in trading relationships, unstable markets and the injustices of conventional trade.
\end{abstract}

Keyword: Large-Scale Retailers; Fair Trade Market; Ethical Products; Sustainability; Private Label; Over-supply; Market-Driven Management; European Retailers

\section{The Fair Trade Market}

The global food system is in a particularly critical situation over the conditions in which food is cultivated, transformed and distributed.

At the head of the chain, small farmers (who produce $70 \%$ of the world's food) are first affected by the imbalance: the world over, half the population of small farmers lives in abject poverty despite that they farm some of the most profitable crops on the international market (coffee, cocoa, tea, sugar, exotic fruit, etc.)

Constantly rising and volatile food prices, fertilizers and fuel costs weigh increasingly heavily on the pockets of the poorest families who cultivate the land and spend $75 \%$ of their earnings on food, without bringing home enough money to provide a decent standard of living for themselves and their families.

The situation of small farmers is even more worrying when considering that according to some estimates production will have to double by 2050 to meet the increasing global demand for food.

At the same time, consumers in industrialized nations waste over 220 million tons of food every year, equal to the entire food production figure for sub-Saharan Africa. One of the latest World Health Organization reports states that in terms of reduced life expectancy, the costs related to overeating are greater than those related to malnutrition.

Climate change is exacerbating the situation and is threatening coffee, cocoa, sugar, tea and fruit crops on a global scale.

Many companies in the food industry are increasingly taking action to ensure constant, 'guaranteed' sustainable supplies of raw materials and key supply chain products.

\footnotetext{
* Invited Article

*** Director, Fairtrade Italia (direzione@ fairtrade.it)
}

Edited by: ISTEI - University of Milan-Bicocca

ISSN: 1593-0319

Pastore, P. (2015). Companies and Consumers Together for a More Ethical Market, Symphonya. Emerging Issues in Management (symphonya.unimib.it), 5, 41-45. 
In this context, fairtrade standards are an important and indispensable element for many global retailers who are greatly integrating guaranteed products into their consumer mix and basic raw material supply policies.

This is most evident in Northern European markets that lead the field in dealing with these problems, bringing about a veritable boom in consumption.

Table 1: Estimated Retail Value for Consumption (euro - 2015)

\begin{tabular}{|c|c|}
\hline Switzerland & 500 million \\
\hline Germany & 1 billion \\
\hline UK & 1.67 billion \\
\hline
\end{tabular}

The numbers show exponential double-figure growth in recent years when compared to the estimated 100 million euro Italian market in 2015, excluding estimates on per capita consumption.

\section{The Virtuous Example of Switzerland}

Swiss retailers stock fairtrade certified products not just to meet the demands of committed consumers or a niche market, but fully adopt fairtrade policies in their private label strategy. A noteworthy example is Coop Switzerland that fairtrade certifies its entire private label range of chocolate and coffee, thereby achieving a series of significant results:

- Conferring its assortment with globally ethical features

- Making a distinctive choice compared to competitors

- Sending an important message to customers, stakeholders and consumers, or rather, creating an ethical, sustainable consumption environment with over 500 products available in all product categories.

\section{The British and German Market}

In the UK, large supermarkets have chosen the fairtrade supply chain for about $50 \%$ of their coffee assortments. Furthermore, Sainsbury's, Waitrose and Co-op UK have substituted their key branded labels with fairtrade certified products. In terms of chocolate and tea, around half the stores carry an assortment of around 150 of these products.

In Germany, three big name supermarkets as well as discount retailers Lidl and Kaufland deal with the assortment issue organically. Rewe and Edeka joined the Fairtrade Sourcing Program that enables companies to source certified products in a percentage that increases over time (particularly sugar, cocoa powder and cotton), phasing it into their private label product range.

Germany is the European leader in distributing fairtrade cotton shopping bags with around 1.5 million units in one year.

The overall result is that fairtrade assortments of varying sizes are available in over 45,000 stores throughout the European Union that meet family consumption needs. 


\section{Consumer Sensitivity - Loyalty to Retailers}

The fairtrade product range would not enjoy such rapid, massive development if consumers were unconcerned and uninterested in learning the story behind the products they buy, the living and working conditions of those cultivating the food, the origin, how the price is formulated and the social, economic and environmental sustainability of what they buy. For these reasons, consumers are prepared to spend more and the fairtrade logo represents these values, as attested by its recognition rate.

\section{Some Considerations on the Southern European Market}

Despite the enormous potential, Southern Europe (particularly Italy and Spain) is still a niche market for fairtrade certified products, even if growing as the following figure shows:

Figure 1: Sales in Italy - 2002-2014

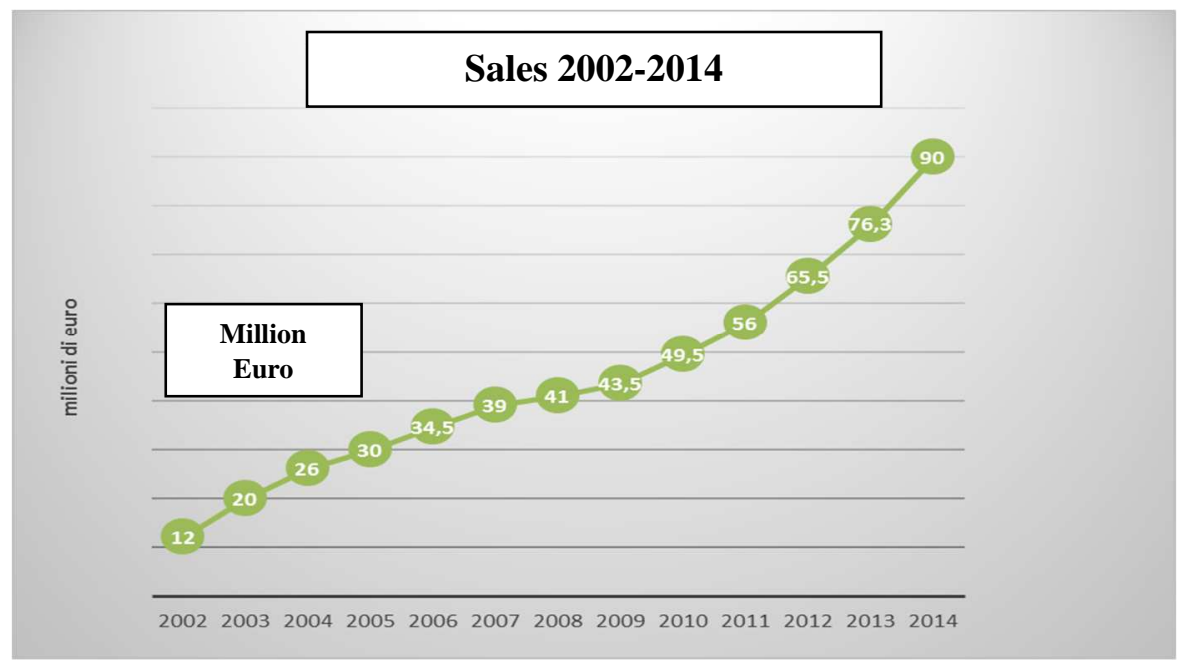

The retail value continued to grow in 2015, with the following estimated figures:

- Italy: 99 million euro

- Spain: 29 million euro.

The ethical production chain markets in Southern Europe are negatively affected by some critical factors that can be summed up as:

- Fragmented distribution structure

- Perception of 'solidarity'

- Consumers not very willing to experiment and try new things

- Big name supermarket chains resist implementing this innovative instrument.

In some respects, there has been a change in direction, particularly driven by

Coop Italia, the first to choose fairtrade in its private label products. The 'conversion' to fairtrade for its entire range of teas dates back many years while it 
is currently testing innovative tropical fruit choices (loose bananas, out-of-season tropical fruit) in some particularly mature regions (Lombardy and Piedmont).

Other openings are beginning to emerge among competitors such as Conad, Selex and Carrefour, which are approaching fairtrade supply chains for organic agricultural produce, thus bringing organic and fairtrade together under the umbrella of social and environmental sustainability.

The Stock Keeping Unit (SKU) numbers in the assortments indicate the success of such referencing even if not supported by the same intensity of promotion as the food retail sector generally in recent years, yet indicating that the fairtrade message and supply chains are 'attracting' consumers due to the values they embody.

\section{Emerging Markets - South-South Fair Trade}

Fairtrade International has also begun to explore emerging economic markets, establishing operational bases in Africa, the Far East and Latin America, with a special focus on India, South Korea, Brazil and South Africa. These countries produce and market fairtrade products and an increasing portion of the population has enough income and spending power to consider the available consumer product supply chains.

This market project started in 2013 and the latest available data show an overall figure of round 100 million euros in retail value, small by all means, but indicating growing interest and the potential development and strengthening of these markets.

\section{Conclusions}

The indications we can draw from this brief overview can be summarized as follows:

- Food and supply chain sustainability is an imperative, not an option for companies seeking guaranteed quality supply chains and customer loyalty in their product sourcing policy.

- Consumers, including the new generation, are choosing products with less impact on the environment and on society with an appropriate quality-price ratio.

- The near future calls for a new development model that brings together all supply chain stakeholders with strict and reliable controls along the entire value chain.

\section{Bibliography}

Arrigo, E. (2010) Innovation and Market-Driven Management in Fast Fashion Companies, Symphonya. Emerging Issues in Management (symphonya.unimib.it), 2, 67-85.

http://dx.doi.org/10.4468/2010.2.06arrigo

Brondoni, S.M. (2011). Global Networks, Knowledge Management and World Cities. Symphonya, Emerging Issues in Management (symphonya.unimib.it), 1, 7-18.

http://dx.doi.org/10.4468/2011.1.02brondoni 
Brondoni, S.M. (2012) Innovation and Imitation: Corporate Strategies for Global Competition, Symphonya. Emerging Issues in Management (symphonya.unimib.it), 1, 10-24.

http://dx.doi.org/10.4468/2012.1.02brondoni

Fairtrade Foundation (2013). Powering up Smallholder Farmers to Make Food Fair.

Fairtrade International Annual Report (2015). Global Change, Local Leadership.

Food and Agriculture Organization (2014), The State of Food and Agriculture.

Gnecchi, F. (2013). Retailing, Private Label and Global Competition, Symphonya. Emerging Issues in Management (symphonya.unimib.it), 2, 79 - 87.

http://dx.doi.org/10.4468/2013.2.06gnecchi

Institution of Mechanical Engineers (2013), Global Food Waste Not, Want Not.

International Fund for Agricultural Development (2010), The Future of Food Safety Around the World.

Loureiroa, M. L., \& Lotadeb, J. (2005). Do Fair Trade and Eco-labels in Coffee Wake Up the Consumer Conscience? Ecological Economics, 53 (1), 129-138.

http://dx.doi.org/10.1016/j.ecolecon.2004.11.002

Moore, G. (2004). The Fair Trade Movement: Parameters, Issues and Future Research, Journal of Business Ethics, 53 (1), 73-86.

http://dx.doi.org/10.1023/B:BUSI.0000039400.57827.c3

Mulhern, F. J. (1997). Retail Marketing: From Distribution to Integration, International Journal of Research in Marketing, 14 (2), 103-124.

http://dx.doi.org/10.1016/S0167-8116(96)00031-6

Nicholls, A. J. (2002). Strategic Options in Fair Trade Retailing, International Journal of Retail \& Distribution Management, 30 (1), 6-17.

http://dx.doi.org/10.1108/09590550210415220

Renard, M. C. (2003). Fair Trade: Quality, Market and Conventions, Journal of Rural Studies, 19 (1), 87-96.

http://dx.doi.org/10.1016/S0743-0167(02)00051-7

Riboldazzi, S. (2015). R\&D and Product Engineering in Global Pharmaceutical Companies, Symphonya. Emerging Issues in Management (symphonya.unimib.it), 2, 57-74.

http://dx.doi.org/10.4468/2015.2.05riboldazzi

Salvioni, D. M., Intangible Assets and Internal Controls in Global Companies, Symphonya. Emerging Issues in Management (symphonya.unimib.it), 2, 2010, 39-51.

http://dx.doi.org/10.4468/2010.2.4salvioni

Witkowski, T. H. (2005). Fair Trade Marketing: An Alternative System for Globalization and Development, Journal of Marketing Theory and Practice, 13 (4), 22-33.

http://dx.doi.org/10.1080/10696679.2005.11658556 